DOI: https://doi.org/10.46630/phm.12.2020.36

Милан Б. Громовић ${ }^{1}$

Универзитет у Новом Саду

Филозофски факултет

Одсек за српску књижевност и језик
Оригинални научни рад УДК 821.163.41.09-24 Симовић Љ.

Примљен: 31. 3. 2019.

\title{
СТРУКТУРА МИТСКЕ СЛИКЕ У ИСТОРИЈСКИМ ДРАМАМА БОЈ НА КОСОВУ И БОЈ НА КОСОВУ, ДРУГА ВЕРЗИЈА ЉУБОМИРА СИМОВИЋА
}

Циљ овог рада јесте анализа Симовићевог односа према миту, који је у извесној мери иронијски, као и упућивање на друга читања мотива жртвовања у драмама Бој на Косову и Бој на Косову, друга верзија. Драме Љубомира Симовића говоре о Косову из усмене традиције, које је симбол апокалиптичног урушавања српске државе, државности, политичке самосталности, али и целог српског народа. Историја у Косовској бици не види овакву величину и пресудни значај, док је у усменој епици присутна слика Косова као краја света („последње време“). Централни неизмењени мит, који је преузет из усмене традиције, у драми Бој на Косову, поред ауторове тврдње, ипак бива додатно оплемењен драмском иронијом. У драмама Љубомира Симовића, без обзира на време, ликови говоре једним истим језиком, без архаизама. То указује на пишчеву опредељеност да изједначи људске судбине, укидајући им историчност, како би их уздигао до митске свевремености.

Кључне речи: Косовски мит, Љубомир Симовић, жртвовање, царство небеско, српски духовни простор

\section{1. Немогућност реконструкције мита}

Драме Љубомира Симовића карактеристичне су по отклону од система традиционалне културе који их сврстава у врхове српске драме двадесетог века. Симовић 1989. године, у којој је обележена шестогодишњица Косовске битке, објављује драму Бој на Косову (СКЗ, Београдски издавачко-графички завод, Београд, 1989), која у себи нема отклона од традиције. Овај драмски текст узет је за сценарио за истоимени филм Здравка Шотре који је пригодно снимљен исте године. Друга верзија драме објављена је четрнаест година касније, у нешто другачијим политич-

${ }^{1}$ milan.grom@gmail.com 
ким и друштвеним околностима: Бој на Косову: Друга верзија (Стубови културе, Београд, 2003). Симовићево придржавање основног, у великој мери, „окамењеног“ обрасца приказивања косовског мита, део је актуелног културолошког и политичког схватања идентитета у српском народу. Сви писци у српској књижевности, који су имали намеру да литерарно осветле косовски мит, наилазили су на један исти проблем нелитерарне природе.

Писац историјске драме мора имати у виду све препреке које могу негативно утицати на будућу рецепцију дела, нарочито ако је реч о историјском догађају који представља кључну тачку одрживости националног идентитета. Драми Љубомира Симовића претходи корпус драма 2 које своје тематско тежиште ослањају на мит о Косову или се извесним мотивима повезују са њим (мотив Лазареве жртве, јунаштво Милоша Обилића или издаја од стране Вука Бранковића): Сима Милутиновић Сарајлија, Трагедија Обилић (1827), Јован Стерија Поповић, Милои Обилић (1828), Матија Бан, Цар Лазар (1858, 1866), Јован Суботић, Милош Обилић (1864), Милош Цветић, Лазар (1889), Иво Војновић, Смрт Мајке Југовића (1906), Миладин Шеварлић, Пропаст цуарства српскога (1980), Косово (1988), Змај од Србије (1990) и др. ${ }^{3}$

Заједничко тематско полазиште свих наведених драмских текстова јесте историјски догађај који је прерастао у мит о великој и пресудној бици српског народа. Таква основа чини први (историјски) $)^{4}$ елемент књижевног жанра историјске драме. Други (драмски) сегмент, који има

\footnotetext{
2 У српској књижевности заснована је својеврсна традиција драмског стварања на тему Косова, која је испратила сва историјска и политичка превирања на територији српске државе и која је увек изнова актуелизована. Потреба за њеним стварањем и развијањем била је насушна. Љубомир Симовић у своје две верзије драме о Косовском боју није остварио интертекстуалне везе са корпусом историјских драма које су настајале од 19. века до настанка његовог дела. То не мора значити да их није имао у виду, већ да ниједна од њих није могла да одгонетне сврсисходан приступ драматизацији ове велике теме, која би била лишена нелитерарних елемената и „спољашњих“ утицаја.

${ }^{3}$ Списку српских историјских драма о Косову неопходно је додати Горски вијенаи Петра Петровића Његоша, који жанровски не припада овом корпусу, али је тематски веома близак. Величање Обилићевог јунаштва и косовског завета у Горском вијениу засигурно представља аутентичан поглед на косовски мит, који поред литерарног обухвата и филозофско становиште.

${ }^{4}$ Историјски елемент историјске драме у себи садржи мит, како би драматизација била успешна. Заправо, важно је да тај мит у историји аутор стваралачки актуелизује на најбољи начин. У том контексту важно је споменути став Јулијуса Еволе, који релативизује стереотипно схватање мита и историје: „...са становишта 'науке' мит се вреднује сходно томе колико у њему има историје, с нашег становишта се, пак, самој историји даје вредност у складу с тим колико она може да пружи митскога или колико је ту митова који се увлаче у њене догађаје, употпуњавајући сам њен 'смисао'“ (EVOLA 2010: 14).
} 
задатак да приказује (домишља, онеобичава) „...оно што се могло догодити, и што је могуће по законима вероватноће и нужности...“ (Аристотел, O песничкој уметности) у свим овим драмама, делимично или у потпуности, подређен је првом (историјском) сегменту. Сваки покушај одступања од „правила“" са битком и прецизно утврђене односе међу ликовима и њиховим карактерима, био би од стране публике осуђен на пропаст. Овим проблемом у српским историјским драмама о Косовском боју бавила се Марта Фрајнд у књизи Историја у драми драма у историји. Ауторка књиге истиче да друштвене и политичке околности у којима настају драме имају великог утицаја на њихово обликовање; као и непрестана актуелност дубоке трауме, која је настала на Косову 1389. и која до данашњег дана бди у свести српског народа:

„Духовна суштина Косовске легенде и начин њеног уметничког обликовања били су заувек утврђени и непроменљиви [...]. Докле год Косово буде постојало као актуелни историјски и политички проблем, Косовска легенда и њена књижевна тумачења биће неизбежно ограничени на своју првобитну форму, јер само у њој могу да функционишу као идеолошки, национални и етички фактор у свести српских читалаца и гледалаца““ (FRAJND 1996: 180-181).

Када је у питању поезија Љубомира Симовића, важно је рећи да обилује истанцама мита према свакодневици, где често долази и до пародије мита (нпр. у песми „Леда“). Симовић као песник негира и деградира мит, који је „деформисан, што значи да постаје жртва гротеске“ (VLADUŠIĆ 2018: 47). Мит у његовом песништву одређује раскид са историјом и отклон од елиотовског доживљаја традиције, како би се потрага за стварношћу која ће приказати предметни свет песме усмерила у другим смеровима изван оквира културно-историјског памћења. Одломак из једног интервјуа илуструје ауторов однос према косовском миту 6 , из чега се може закључити да је у питању свесно одрицање од реконструкције или додатног онеобичавања основног митског обрасца. Разлог за то је непогодан историјски тренутак, баш као код сваког писца исто-

\footnotetext{
${ }^{5}$ У смислу рецепције, „Правилан“ однос према Косовском миту дефинисан је усменим предањем, а свако одступање у српској ауторској књижевности наилази на отпор код читалаца. Промена (еволуција) рецепције дела са темом Косова у каузалној је вези са мењањем друштвенополитичких догађаја у Србији.

${ }^{6}$ „Иронија је мач са две оштрице. Она може да буде и лакши пут, којим се заобилазе тешкоће у читању и тумачењу мита. Ништа лакше него показати ироничан однос према важним стварима и светињама. (...) Што се тиче мог односа према косовској теми, мислим да сада није време за иронију. Што не значи да мислим да је време за идеализацију. Обе те крајности, и иронија, и идеализација, најчешће су знак недостатка стварних идеја“ (SIMOVIĆ 1991b: 125).
} 
ријске драме са темом Косова. Јасна је чињеница да је историјска драма о осетљивим питањима више окренута историји „данас“, него историји ,jуче“, иако је суштински елемент овог жанра, и књижевности уопште, прожимање синхронијског и дијахронијског сагледавања историје (X. Г. Гадамер). Предметни свет Симовићеве драме идеализован је до извесне мере, што није погодно тле за формирање драме, али, са друге стране, аутор указује на могућности интерпретације универзалних значењских категорија косовског мита, као што су: поглед на свет духовним и телесним очима; свест о трошности царства земаљског и залога непропадљиве будућности у царству небеском; витешка част и жртва и др. Идеализована митска слика у драми Бој на Косову има идеолошку функцију. Реч је о својеврсној актуелној политичкој условљености овог текста која Симовићеву драму у појединим деловима потпуно подређује времену „данас“, односно 1989. години, у којој се изнова активира до данас осетљиво политичко питање - Косово.

Важно је истаћи да је вредност друге верзије драме Љубомира Симовића у томе што су ова „слаба места“ потпуно неутралисана и што је тематско тежиште усредсређено, онолико колико је то могуће у 2003. години, на Косово из 1389. Да је аутор неким случајем писао другу верзију свог дела у 2004. години (када горе српски манастири на Косову) или у 2008. (када јужна српска покрајина бива насилно отцепљена од Србије), нажалост, морао би да на своје перо постави још тежи тег. Уз другу верзију драме Симовић је приложио уводни текст „Увод у читање новог Боја на Косову“ у којем говори о „немогућности разабирања у плетиву“ у које се уплео покушајем да реконструише косовски мит:

\begin{abstract}
„Међутим, током писања, све више сам постајао свестан колико ме тај материјал, који се поштује као врхунски израз наше националне идеологије, религије и етике, обавезује, то јест колико ми мало слободног простора оставља. Схватио сам шта се од писца, који се тим материјалом користи, очекује. И та сам очекивања, прво, почео да узимам у обзир, а потом, а да то честито нисам ни приметио, и да их испуњавам. Што сам их више испуњавао, био сам све даље од онога што сам у почетку намеравао да учиним“ (SIMOVIĆ 2003: 185-186).
\end{abstract}

О суровим ограничењима (захтеви рецепције са једне и стваралачка креативност са друге стране) са којима се сусрео Љубомир Симовић, као и сви други аутори, који су косовску тему хтели да прикажу у својим драмама, пише Бошко Сувајџић у студији Дновиде воде: Фолклорни елементи у српској књижевности:

„Стваралачка драма коју описује Љубомир Симовић на сличан начин се поставља пред све ауторе који су се подухватили драматуршке обраде косовске теме. Теме у којој је све већ познато, одређено, унапред задато. 
Теме која стога пружа тако мало простора за варирање наслеђене грађе“ (SUVAJDŽIĆ 2012: 81).

\section{2. Иронија, жртва, жртвовање}

Драма Бој на Косову говори о Косову из усмене традиције - симболу апокалиптичног урушавања српске феудалне државе, политичке самосталности, верске и културне слободе читавог српског народа. Историја у Косовској бици не види значај ових размера, док је, насупрот томе, у усменој епици присутна слика Косова као краја света тј. „последњег времена““ ${ }^{7}$ Централни неизмењени мит у Симовићевом делу, поред ауторове тврдње, ипак бива додатно оплемењен драмском иронијом, која би могла да додатно оплемени и реконструише мит. Иронијски елементи учествују у приказивању живота појединаца, који су окренути царству земаљском и којима је једина брига од чега ће себи обезбедити егзистенцију. Без обзира на време и околности у којима живе, ликови Симовићевих драма говоре једним истим језиком, без архаизама. То указује на пишчеву опредељеност да људске судбине доведе у једну раван, укидајући им историчност, како би их уздигао до митске свевремености. На тај начин језик Симовићевих јунака сеже у митску свевременост и указује на присуство универзалних архетипских образаца у његовом делу:

„Љубомир Симовић руководи се откривањем два аспекта откривања егзистенцијалног бића, оног текућег, свакодневног и савременог, везаног за конкретни историјски тренутак и оног који трајно прати сваку егзистенцију јер допире до искони и могао би се назвати колективним“ (VRBAVAC 2005: 94).

Јунак којем Љубомир Симовић посвећује највише пажње у драми Бој на Косову не припада свету владара, вођа и политичара. Иако се може приметити извесна идеализација Лазаревих беседа, народ је тај којем је дата титула главног актера драме. Ликови проналазе суштину бивствовања једино на Косову, а сви они заједно чине Народ, који је спреман да принесе себе као жртву за косовско опредељење. Аутор негира постојање ироније и идеализације у приступу косовској теми, али контекст иронијс-

\footnotetext{
${ }^{7}$ Историја Косовску битку не сматра пресудном за пораз српске државе у средњем веку, јер је српски народ државност изгубио тек падом Смедерва (1459), односно након низа пораза који су уследили после Косова. Развој косовског мита у усменој епици настао је из жеље за оправдањем пораза српске државе, о којем је требало испевати еп. Сила историјских (не)прилика учинила је да не дође до груписања епског блага у једну епску целину, али је дошло до формирања циклуса епских песама, које до детаља разгранавају и уоквирују највећи српски мит. За ову „другу историју човечанства“ опредељује се Љубомир Симовић.
} 
ког смештен је у други план. Јасмина Врбавац, када говори о иронизованом миту у Симовићевој драми Бој на Косову, иронију препознаје кроз одјеке боја у народу: „Кроз различите нијансе људске судбине Симовић говори о жртви и жртвовању“ (VRBAVAC 2005: 98). Љубомир Симовић нијансира мотив жртвовања кроз ликове обичних људи из народа. Свесно се жртвују: Велислава, млекарица и водоноша; жртве властите судбине су: Косовка Девојка, Војиша; на улогу жртве ни у једном тренутку не пристаје Рибарица. Иронија је најзаступљенија у карактеризацији Рибарице, коју највише занима материјална добит и спас властите главе, што се потврђује на два места у драми. Она поставља питање: „Једу ли Турци рибу?“, као и питања у вези са променом новчане валуте, јер се под новим господарем мора мењати и новац. Рибарицу одликује одсуство бриге за колективну пропаст, јер не жели да види даље од властитих потешкоћа које настају губитком српске војске на Косову. Лик Рибарице до краја је „демитологизован“ и иронијски се пореди са Исусом: „Остала сам са две рибе к’о Христос.“ Поред видара Богоја, који је спреман да „прода веру за вечеру“, иако то читалац не зна до расплета догађаја, Рибарица је типични представник оног дела српског народа који би, нажалост, олако изабрао опредељење за пут „са Косова“.

Кључни смисао жртвовања у драми Бој на Косову јесте поглед преко „границе“ у други свет („где човеку почињу да расту перје, чекиња, крљушт...“), а цена за то је одрицање очињег вида. Драматизована слика, у којој се поставља контраст светог и проклетог, приказана је кроз дијалог слепог монаха Теофана и јеромонаха Макарија. Теофан говори о горњој и о доњој граници, и види пут много даље од свог саговорника - „магла му не смета јер је не види, а Макарију смета зато што је види“.

Горња граница је граница светла, а доња граница мрака. Макарије у црном облаку види судију, као да је дошао Страшни суд. У овој слици присутни су мотиви риба и крилатих гуја које гутају грешнике, што подсећа на Симовићеву песму „Поплава“". Пут до духовног простора Косова видљив је слепом монаху, чиме Косово добија једну врсту трансценденталне симболике. Према мишљењу Јасмине Врбавац: „Симовић на темељима архетипског мотива о слепом и видовитом, твори митему о неопходности жртве без које нема духовног преображаја; митему која би се могла назвати и својеврсном поентом драме, али и централном митемом његовог драмског дела“ (Исто). Шире посматрано, цео Народ заједно са својим царем, мора затворити земаљске очи и „са Косова“ се вратити кроз ,земљане двери“ у „царство небеско“. Плач Косовке Девојке, која је жртва властите судбине, представља причу о другом свету у који ће њен вереник и други јунаци „васкрснути“ након боја: „Испраћам га на врата од злата; дочекујем на земљана врата. [...] Која ће ти земља, која пти- 
ца; која река, бити вереница? [... $]^{8}$ Христе, златно и црвено слово; зашто нисам лишће јасиково“ (SIMOVIĆ 1991a: 75-77). Симболика загробног живота на овом месту у драми експресивно је приказана кроз жељу за синтезом са мртвим драгим.

Поред сцена у којима људска патња долази до врхунца (плач Косовке Девојке) и ироничних слика „малих људи“ и њиховог минорног морала (Рибарица и Богоје) постоје и места у драми на којима се иронија прелива у смех. У десетој сцени прве верзије драме, под насловом „Котур длакавог сира“, дијалог између Војише и Богоја започиње расправом о сиру која прераста у смех. Војиша се најпре чуди када му Богоје даје длакави сир који га подсећа на јазавца, а потом одбија да једе са њим. Трагикомично у истом дијалогу је Богојево жаљење због изломљених зуба, јер су га: „Хранила браћа дрвеним крушкама“ (SIMOVIĆ 1991: 84). На почетку овог рада истакнуто је да друге Симовићеве драме поседују отклон од традиције, а да то није сличај са драмом Бој на Косову:

„У Симовићевим драмама, као што су Чудо у Шаргану, Хасанагиница и друге, судбинска предодређеност ликова увек је изнад могућности избора, док у драми Бој на Косову постоји супротна ситуација. То се може схватити као разлика између паганског и хришћанског мита, односно, између паганског и хришћанског погледа на свет“ (VRBAVAC 2005: 96).

Иронија у ликовима превртљивог видара Богоја и „лако прилагодљиве“ Рибарице, јесте ауторова интенција за потрагом објашњења унутар њихове судбинске предодређености да буду жртве. Не жртве које се свесно жртвују за царство небеско, већ несвесне, оне које појединце воде у амбис пропадљивог и материјалистичког царства земаљског.

Драма Бој на Косову: Друга верзија још више је приближена свакодневици и животу обичних људи, чиме се остварује дистанца према миту, али се митска слика не оставља предалеко од контекста дела. Аутор је у другој верзији свог дела достигао дуго тражену поетску „страсну меру“, о којој је певао Иван В. Лалић у својој поезији. Уз помоћ поезије, која у драми живи кроз говор ликова, Љубомир Симовић је дошао до искони и мита:

„Бој на Косову Љубомира Симовића у новој, преправљеној верзији изузетно је мудра драма. Удаљена од косовске легенде таман толико да се у њу не утопи, блиска осећањима обичних људи, рибарица и пиљарица, она је израз врхунске поезије у драмској форми. Симовић је успео да представи сву непроцењиву шароликост свакодневног живота који је највиша мера људског трајања, и када се око њега великаши погађају и ценкају на пијаци таштине. Живота који је неуништив и непролазан и онда када се налази 'у сенци дворова, Лазаревог и Вуковог', и онда када те сенке нестане“ (SUVAJDŽIĆ 2012: 90).

\footnotetext{
${ }^{8}$ Курзив М. Г.
} 


\section{3. Митска слика простора}

На почетку прве верзије драме, из разговора видара Богоја и слепог монаха Теофана јасно је наговештено да „Данас у Србији нема другога пута до пута на Косово, или са Косова!““(SIMOVIĆ 1991a: 11). Путеви „на Косово“ или „са Косова“ једини су могући, па сходно томе пред ликовима Симовићеве драме јавља се неминовност избора. У драми Бој на косову, као у народној епској песми „Кнежева вечера“, неопходно је да се зна ко ће бити „вјера“, а ко „невјера“: „Сјутра јесте лијеп Видов данак, / Виђећемо у пољу Косову, / Ко је вјера, ко ли је невјера“ (KARADŽIĆ 1969: 225-226). Према мишљењу Љиљане Пешикан Љуштановић, у Теофановом одговору „оцртава се основна историјска и морална дилема с којом се суочавају ликови, али се, с друге стране, нарушава, драмски изузетно сугестивна усмереност искључиво 'ка Косову', која гради драмску напетост, ишчекивање ко тим јединим могућим путем неће поћи“ (PEŠIKAN LJUŠTANOVIĆ 2010: 395-408). Питање о путу који на Косово води јесте основно питање и у првом делу друге верзије драме; у тренутку када Праља посматра пролазнике и сведочи о томе да готово сви иду према Косову (SIMOVIĆ 2003: 9-10). Могућност да неко изабере пут „са Косова“ не постоји, „све до часа када Вук Бранковић то одиста учини - и буквално (повлачећи се) и симболички (издајући Лазара)“ (PEŠIKAN LJUŠTTANOVIĆ 2010: 408).

У обе варијанте Симовићеве драме садржан је низ слика које сугеришу слику простора. Друга верзија драме знатно је сведенија у односу на прву, па слика простора има квантитативно мање, али постоји разлика у квалитету. Простори о којима се прича јесу од круцијалне важности за карактеризацију ликова. Нпр. Милош Обилић када спашава видара Богоја од страже Вука Бранковића споменуће битку на Плочнику, у којој му је Богоје извидао рану. Обилић Богоју напомиње да га је више болело лечење него рањавање, после чега читалац стиче заокруженији увид у карактер видара. Предео који види слепи монах Теофан чист је и прозиран, без обзира на густу маглу и одсуство очињег вида. То може представљати назнаку митског карактера овог јунака. Простор Косова у драми Бој на Косову може се схватити као реалан простор на коме се одвија битка, али и као метафизички, духовни простор суштине постојања целог српског национа. Митска слика простора Косова у Симовићеву драму уводи две приче са универзалним значењем: хришћанска жртва за царство небеско и племенити витешки пораз. 


\section{4. Жртвовање краља за царство небеско}

Симовићево интересовање за Лазареву историјску личност јесте велико, али је у грађењу његовог лика у драми већи удео имао Лазарев култ мученика који је у српској књижевности почео да живи од тренутка његове погибије. Кнез Лазар је имао великих заслуга за српску цркву и државу, због чега његов лик у драми поседује карактерне црте храброг верника и још храбријег државника:

„Бранећи српску државу и хришћанску веру од Турака, завршавајући живот мученичком смрћу на Косову 1389. године, погинули српски кнез је стекао заслуге за прослављање. Он је био оличење свих оних који су погинули мученичком смрћу. Стога је и средишна тема култних списа Лазарев крај. Косовски списи с краја 14. и почетка 15. века негују култ мученика. (...) ...у тим текстовима не инсистира се на пасивној кнежевој смрти, већ на томе да се вечни живот и спасење могу стећи отпором, борбом и одбраном Христове вере, опредељењем за царство небеско“ (REĐEP 2007: 22).

Беседе кнеза Лазара Хребељановића у Симовићевој драми, приближавају читаоцу моралну, политичку, историјску и националну страну првог човека Србије тога времена. Лазар је до те мере одлучан у жртвовању и у одласку у „сигурну смрт“ да на сваки проговор о егзистенцији и избегавању сукоба реагује одлучно и одсечно. Ликови попут: Милице, Тамнавца, Левчанина и српског патријарха Спиридона, на посредан начин покушавају да изврше утицај на Лазареву одлуку, у чему не успевају. У другој верзији драме Бој на Косову, непосредно пред бој, Лазар се обраћа патријарху Спиридону и истиче величину причешћа војске: „Сакупљај све митрополите и владике, све синђеле и протосинђеле, архијереје, архимандрите, монахе, јеромонахе, свештенике, ђаконе, ђаке и испоснике, из свих цркава, скитова, испосница, широм Србије, да нам војску причесте пре битке“ (SIMOVIĆ 2003: 15). Поред причешћа целокупне војске и свих учесника боја, хришћански владар Лазар и вечеру пред бој доживљава као свето причешће, што потврђује и низ екскламација у његовом обраћању учесницима кнежеве вечере: „Ово је више причешће, него вечера! Јешћемо оно што је јео Христос! Јер ћемо сутра бити Христови ратници“ (SIMOVIĆ 1991a: 106). И „Молитва кнеза Лазара над косовском трпезом“ додатно појачава експресивност и хришћанску симболику жртвовања за „царство небеско“ у Лазаревој беседи.

\section{5. Хришћански и прасловенски корени косовског мита}

Косовски мит, преузет из српске усмене традиције, у Симовићевом делу добија знатно шире размере. Драматизовани мит отвара могућност 
дубљег интертекстуалног тумачења. Доследно драматизована прича о смрти два краља, о издаји, о храбром витезу и јунаку, препознатљива је и у два друга контекста. Прва асоцијација, несумњиво, јесте Библија. Између Симовићевих драмских ликова и библијских личности постоје извесне паралеле, изведене према сличности у карактерима: кнез Лазар $\rightarrow$ Исус Христ (опредељење за „царство небеско“); Милош Обилић $\rightarrow$ жртва (витешка част и племенити витешки пораз); Вук Бранковић $\rightarrow$ Јуда (издајник). Централни мит Симовићеве драме (косовски мит), представља адаптирану верзију новозаветног мита о жртвовању Исуса Христа, јер кнез Лазар бира својевољно да се жртвује, како би се сходно хришћанском разумевању односа живота и смрти удостојио „царства небеског“

Са друге стране, у Лазаревој жртви и у косовском миту уопште, постоје остаци колективног прасловенског културног наслеђа. Александар Лома у књизи Пракосово: Словенски и индоевропски корени српске епике 9 говори о пореклу приче о специфичној бици, којој претходи „Кнежева вечера“" и у којој гину оба владара, а при том се појављују издајник и храбри ратник из народа. На целокупном старословенском простору, у етимолошким језичким траговима и у усменим творевинама постоје назнаке приче митског карактера сличног типа.

Љубомир Симовић својим делом стваралачки актуелизује мит који у себи носи елементе хришћанског и прасловенског, а његови јунаци својим карактерима обједињују широк спектар хришћанских и прасловенских (у великој мери паганских) врлина. Са једне стране је њихово опредељење за царство небеско хришћанска вера, док је на другој страни српска / словенска традиционална културна баштина: низ обичаја, тужбалица, предсказања, мрачних наслућивања трагедије, предвиђање издајства и сл, која представља неизоставан елемент духовног бића обичног човека тога доба.

\section{Цитирана литература}

EVOLA 2010: EVOLA, Julijus. Pobuna protiv modernog sveta. Čačak, Beograd: Gradac, 2010. [orig.] ЕВОЛА, Јулијус. Побуна против модерног света. Чачак, Београд: Градац, 2010.

FRAJND 1996: FRAJND, Marta. Istorija u drami drama u istoriji. Novi Sad: Prometej, Institut za književnost, Sterijino pozorje, 1996. [orig.] ФРАЈНД, Марта. Историја у драми драма у историји. Нови Сад: Прометеј, Институт за књижевност, Стеријино позорје, 1996.

${ }^{9}$ Види поглавље „Пра-Лазар“ у књизи: Лома, Александар. Пракосово: Словенски и индоевропски корени српске епике. Београд: САНУ, 2002, стр: 159-185. 
KARADŽIĆ 1969: KARADŽIĆ, Vuk. Srpske narodne pjesme II. Nedić, V. Beograd: Prosveta, 1969. [orig.] КАРАЏИЋ, Вук. Српске народне пјесме II. Недић, В. Београд: Просвета, 1969.

LOMA 2002: LOMA, Aleksandar. Prakosovo: Slovenski i indoevropski koreni srpske epike. Beograd:

SANU, 2002. [orig.] ЛОМА, Александар. Пракосово: Словенски и индоевропски корени српске епике. Београд: САНУ, 2002.

PEŠIKAN LJUŠTANOVIĆ 2010: PEŠIKAN LJUŠTANOVIĆ, Ljiljana. „Prostor Kosova u Boju na Kosovu Ljubomira Simovića“. Kosovo i Metohija u civilizacijskim tokovima. Pitulić, V, knj. 2, Kosovska Mitrovica: Filozofski fakultet Univerziteta u Prištini, 2010. [orig.] ПЕШИКАН ЉУШТАНОВИЋ, Љиљана. „Простор Косова у Боју на Косову Љубомира Симовића“. Косово и Метохија у цุивилизацијским токовима. Питулић, В, књ. 2, Косовска Митровица: Филозофски факултет Универзитета у Приштини, 2010.

REĐEP 2007: REĐEP, Jelka. Kosovska legenda. Novi Sad: Prometej, 2007. [orig.] РЕЂЕП, Јелка. Косовска легенда. Нови Сад: Прометеј, 2007.

SIMOVIĆ 1991a: SIMOVIĆ, Ljubomir. Boj na Kosovu. Beograd: SKZ, BIGZ, Prosveta, Dečje novine, 1991. [orig.] СИМОВИЋ, Љубомир. Бој на Косову. Београд: СКЗ, БИГЗ, Просвета, Дечје новине, 1991.

SIMOVIĆ 1991b: SIMOVIĆ, Ljubomir. Kovačnica na Čakovini. Beograd: SKZ, BIGZ, Prosveta, Dečje novine, 1991. [orig.] СИМОВИЋ, Љубомир. Ковачница на Чаковини. Београд: СКЗ, БИГЗ, Просвета, Дечје новине,1991.

SIMOVIĆ 2003: SIMOVIĆ, Ljubomir. Boj na Kosovu: Druga verzija. Beograd: Stubovi kulture, 2003. [orig.] СИМОВИЋ, Љубомир. Бој на Косову: Друга верзија. Београд: Стубови културе, 2003.

SUVAJDŽIĆ 2012: SUVAJDŽIĆ, Boško. Dnovide vode: Folklorni elementi u srpskoj književnosti. Novi Sad: Orpheus, 2012. [orig.] СУВАЈџИЋ, Бошко. Дновиде воде: Фолклорни елементи у српској књижевности. Нови Сад: Orpheus, 2012.

VLADUŠIĆ 2018: VLADUŠIĆ, Slobodan. Orfej i zapušač: Uputstvo za upotrebu poezije nakon Eliota i Valerija. Novi Sad: Akademska knjiga, 2018. [orig.] ВЛАДУШИЋ, Слободан. Орфеј и запушач: Упутство за употребу поезије након Елиота и Валерија. Нови Сад: Академска књига, 2018.

VRBAVAC 2005: VRBAVAC, Jasmina. Mit u dramama Ljubomira Simovića. Novi Sad: Pozorišni muzej Vojvodine, 2005. [orig.] ВРБАВАЦ, Јасмина. Мит y драмама Љубомира Симовића. Нови Сад: Позоришни музеј Војводине, 2005 . 
Milan Gromović

\section{KOSOVO MYTH IN HISTORICAL DRAMA BATTLE OF KOSOVO BY LJUBOMIR SIMOVIĆ}

Drama Battle of Kosovo speaks of Kosovo from the oral tradition which is a symbol of apocalyptic collapse of the Serbian state, statehood, political sovereignty, but also entire Serbian nation. History sees no such a greatness and crucial importance in the Battle of Kosovo, oppose to the oral epic immanent image of Kosovo as the end of the world ("the last time"). In addition to the author's statement, in the drama Battle of Kosovo, the central, unaltered, myth taken from the oral tradition, is furthermore refined with dramatic irony. Regardless of the time, in the dramas of Ljubomir Simović' characters speak one same language, without archaisms. It indicates the writer's commitment to even human destinies up by denying their authenticity in order to elevate them to the mythical timelessness.

Keywords: Kosovo myth, Ljubomir Simović, sacrifice, kingdom of heaven, Serbian spiritual space 